\title{
Interactions between the ovary and the local IGF-I axis modulate mammary development in prepubertal heifers
}

\author{
S D K Berry, R D Howard ${ }^{1}$, P M Jobst, $\mathbf{H}$ Jiang $^{2}$ and $\mathbf{R}$ M Akers
}

Department of Dairy Science, Virginia Tech, Blacksburg, Virginia 24061-0315, USA

${ }^{1}$ Virginia-Maryland Regional College of Veterinary Medicine, Blacksburg, Virginia 24061-0442, USA

${ }^{2}$ Department of Animal and Poultry Sciences, Virginia Tech, Blacksburg, Virginia 24061-0306, USA

(Requests for offprints should be addressed to R M Akers; Email: rma@vt.edu)

\begin{abstract}
The objective was to determine the effects of ovariectomy and epithelial-stromal interactions on mammary development and local expression of IGF-I and IGF-binding protein (IGFBP) mRNA in prepubertal heifers. An epithelium-free ('cleared') fat pad (CFP) was prepared in two glands in each of 14 Holstein heifers, aged 1-3 months. Eight of the calves were also ovariectomized. Serum concentrations of GH, IGF-I and prolactin were not affected by ovariectomy. At 6 months of age, calves were killed to provide mammary samples of parenchyma, CFP and intact fat pad (MFP). Total mammary mass was reduced in ovariectomized calves $(130 \pm 21 \mathrm{~g}$ vs $304 \pm$ $25 \mathrm{~g} ; P<0.001)$, and in several cases parenchymal tissue was essentially absent. Uterus weight was also reduced by ovariectomy $(14.5 \pm 3.8 \mathrm{~g}$ vs $30.4 \pm 4.5 \mathrm{~g} ; P<0.05)$. In support of our hypothesis that local IGF-I mediates pre-
\end{abstract}

pubertal mammary development, mRNA expression of IGF-I was lower in ovariectomized than in control calves $(62 \cdot 1 \pm 7 \cdot 8$ vs $91 \cdot 6 \pm 7 \cdot 8$ arbitrary units; $P<0 \cdot 05)$. Specific binding of IGF-I to mammary parenchymal microsomes was also reduced by ovariectomy $(377 \pm 142$ vs $868 \pm 82$ c.p.m.; $P<0 \cdot 01$ ), suggesting decreased sensitivity to IGF-I. Expression of IGFBP-3 and IGFBP-5 mRNA were not influenced by ovariectomy. Expression of IGF-I, IGFBP-3 and IGFBP-5 mRNA did not differ between CFP and MFP, suggesting that expression of these factors was not influenced by interactions between stroma and developing epithelium. Overall, the data suggested that interactions between the ovary and the local IGF-I axis act to optimize the availability and effectiveness of IGF-I within the gland to stimulate mammary growth.

Journal of Endocrinology (2003) 177, 295-304

\section{Introduction}

Development of the bovine mammary gland is accomplished through complex interactions between systemic hormones and locally produced growth factors. Although the majority of mammary development occurs during gestation, a critical period of heifer mammary growth occurs during the prepubertal period of approximately 3 to 9 months of age (Sinha \& Tucker 1968). During this time, mammary growth is allometric and expansion of the ductular tree occurs, providing a foundation for later alveolar development during gestation. Impairment of mammary growth by rapid rearing before puberty results in reduced mammary development and subsequently impaired milk yield during lactation (Sejrsen et al. 2000). Therefore, it appears that mammary development can be manipulated during the prepubertal period to influence later milk yield. Understanding the biology underlying prepubertal mammary growth may lead to novel techniques for enhancing prepubertal mammary development, and subsequent milk yield.
Although growth hormone $(\mathrm{GH})$ and estrogen are stimulators of mammary development (Topper \& Freeman 1980, Tucker 1981, Sejrsen et al. 1986) and mammary epithelial cell proliferation in heifers (Woodward et al. 1993, Berry et al. 2001), the mechanisms by which these hormones act are unclear. Accumulated evidence suggests that locally produced growth factors and their binding proteins, especially insulin-like growth factor (IGF)-I and IGF-binding proteins (IGFBP), may mediate the effects of systemic hormones in the ruminant mammary gland. For example, GH has no proliferative effect on mammary explants or immortalized mammary epithelial cells, but IGF-I is clearly mitogenic (Akers 1990, Hovey et al. 1998b, Weber et al. 1999). Despite recent detection of GH receptor mRNA (Plath-Gabler et al. 2001) and protein (Sinowatz et al. 2000) in bovine mammary tissue, specific binding of $\mathrm{GH}$ to mammary microsomes has never been demonstrated (Akers 1990, McFadden et al. 1990). In contrast, mammary epithelial cells express the IGF-I receptor (Romagnolo et al. 1994, Purup et al. 1995) and IGF-I mRNA is present in both the stromal and 
parenchymal portions of the mammary gland (Hovey et al. 1998a, Weber et al. 2000, Berry et al. 2001). In ewes, periods of rapid mammary growth are correlated with increased expression of mammary IGF-I mRNA (Hovey et al. 1998a) and increased epithelial proliferation in heifers coincided with increased IGF-I and decreased IGFBP-3 (Berry et al. 2001). Estrogen also appears to interact with IGF-I to promote mammary growth. For example, estrogen enhanced the mammogenic effects of IGF-I in prepubertal rats, as well as the ability of GH to stimulate mammary expression of IGF-I mRNA (Ruan et al. 1995). Estrogen has also been shown to stimulate phosphorylation of the insulin-receptor substrate-I (IRS-I; a key component of the IGF-I signaling pathway) in the uterus (Richards et al. 1996) and in estrogen-sensitive MCF-7 breast cancer cells (Lee et al. 1999).

Although the mammary fat pad has previously been considered primarily as structural support for the developing epithelium, growing evidence suggests that stromal tissue may play a more direct, integral role in mammary development (Hovey et al. 1999). For example, optimal production of growth factors by the mammary fat pad may require cross-talk from the developing epithelium. Accordingly, expression of IGF-I mRNA in ewes was lower in epithelium-free fat pad than the intact fat pad during periods of rapid mammary growth (Hovey et al. 1998a). Possibly, the mitogenic effects of GH and estrogen are mediated, at least in part, through increased stromal expression of IGF-I.

The objectives of this experiment were twofold. First, we sought to determine the effects of ovariectomy on mammary development and epithelial proliferation, as well as IGF-I and IGFBP mRNA expression in prepubertal heifers. Secondly, we sought to examine the importance of epithelial-stromal interactions in regulating stromal expression of IGF-I and IGFBP mRNA. We found that interactions between the ovary and local IGF-I axis are important for regulating prepubertal mammary development, but that the presence of developing epithelium did not influence expression of IGF-I or IGFBP mRNA within the mammary fat pad.

\section{Materials and Methods}

\section{Experimental design and sampling}

All experiments were conducted with the approval of the Virginia Tech Animal Care committee (approval number 98-036-DASC). Fourteen newborn Holstein heifer calves were purchased for the experiment. The calves were housed at the Virginia Tech Dairy Center and raised according to standard calf rearing procedures. Animals were assigned to one of two treatments: control or ovariectomized using a completely randomized design. Between 1 and 3 months of age, surgery was performed on each calf to remove the ovaries from animals in the ovariectomy group $(n=8)$, and to prepare an epitheliumfree ('cleared') fat pad (CFP) in each animal $(n=14)$. In total, eight animals were ovariectomized and six animals remained intact. Of the eight ovariectomized animals, four were ovariectomized before 6 weeks of age, and four were ovariectomized between 6 and 12 weeks of age. All 14 animals received a CFP in two out of four glands in the udder (left or right side, randomly determined). The remaining two glands were left intact to serve as internal controls. Blood samples were taken weekly for the duration of the experiment to enable determination of serum IGF-I, GH and prolactin (PRL) concentrations. Calves were purchased in groups and assigned randomly to treatments beginning in August 2000. The last group of calves was purchased in October 2000. Animals were killed between January and April 2001, at 6 months of age, to provide mammary samples of parenchyma (PAR), intact mammary fat pad (MFP) and CFP. Before samples were taken, we confirmed that CFPs were completely free of epithelial tissues. Mammary tissue samples were frozen in liquid nitrogen for later analysis and udder and uterus weights were recorded. Because we were focused on rapid tissue collection, total mammary weights were the only gross measurements made at the time of slaughter. However, we believe that the total weight of mammary gland and fat pad were representative of parenchymal development based on our visual observations of parenchymal tissue available for sampling at the time of slaughter and the data of Purup et al. (1993) showing that ovariectomy reduced both parenchymal tissue weight and total gland weight.

\section{Surgical procedures}

Surgical preparation of CFPs was conducted essentially as described previously (Hovey et al. 2000). Animals were sedated using a combination of intravenously administered xylazine $\mathrm{HCl}$ (Butler Company, Dublin, OH, USA; $0.1 \mathrm{mg} / \mathrm{kg}$ ) and butorphanol tartrate (Fort Dodge Animal Health, Fort Dodge, IA, USA; $0.1 \mathrm{mg} / \mathrm{kg}$ ). Anesthesia was induced using thiopental sodium (Abbott Laboratories, Chicago, IL, USA; $25 \mathrm{mg} / \mathrm{kg}$; i.v.), and maintained by inhalation of halothane in oxygen. Following induction of anesthesia the heifers were placed in dorsal recumbency and the caudo-ventral abdomen and inguinal regions were clipped and aseptically prepared for surgery. CFPs were prepared by en bloc excision of ipsilateral teats and their associated epithelial tissue. An elliptical skin incision encompassing the base of both teats was made and the palpable nodules of epithelial tissue dissected free from the fat pad. Excised tissue and remaining fat pad were inspected to determine that excision of the epithelial tissue was complete. The subcutaneous tissues were apposed using 2-0 polyglycolic acid suture in a simple continuous pattern and the skin was closed using $2-0$ nylon in a continuous horizontal mattress pattern. An ovariectomy 
was performed during the same anesthetic episode for those animals assigned to the ovariectomy group. Ovariectomies were performed via a $10 \mathrm{~cm}$ caudo-ventral midline celiotomy. The ovaries were isolated, the ovarian pedicles clamped and ligated using no. 0 polyglycolic acid suture. The ovaries were excised with scissors. The linea alba was closed using a simple continuous pattern of no. 1 polyglycolic acid. The subcutaneous tissues were closed using 2-0 polyglycolic acid suture in a simple continuous pattern and the skin was closed using 2-0 nylon in a continuous horizontal mattress pattern. Animals were kept in individual pens until they had fully recovered from anesthesia (approximately 1-2 h). Procaine penicillin G $(22000 \mathrm{IU} / \mathrm{kg}$ ) was administered twice daily for 2 days.

\section{$R N A$ isolation and analysis of $m R N A$ expression}

RNA was isolated from PAR, MFP and CFP using Trizol (LifeTech, Rockville, MD, USA), according to the manufacturer's instructions. RNA yield was determined by absorption at $260 \mathrm{~nm}$ and integrity was determined by ethidium bromide staining after agarose-formaldehyde electrophoresis. Twenty micrograms of total RNA suspended in formaldehyde loading buffer (Ambion, Austin, TX, USA) were electrophoresed through a $1 \%$ agarose0.66 M formaldehyde gel. Samples were electrophoresed at $100 \mathrm{~V}$ for $2.5 \mathrm{~h}$ before being photographed to confirm equal loading of RNA. Subsequently, RNA was transferred to Hybond nylon membrane (Amersham, Pistcataway, NJ, USA) by overnight capillary action. Blots were u.v. cross-linked and stored pending Northern analysis. Samples of liver RNA $(10 \mu \mathrm{g})$ and bovine lactating mammary RNA $(10 \mu \mathrm{g})$ were included as positive and negative controls respectively. An ovine $0.7 \mathrm{~kb}$ IGF-I cDNA probe (Ohlsen et al. 1993), a rat 0.44 kb IGFBP-3 cDNA probe (Smith et al. 1990), and a porcine $0.32 \mathrm{~kb}$ IGFBP-5 cDNA probe (White et al. 1996) were labeled with ${ }^{32} \mathrm{P}-\alpha$-dATP using random prime labeling (PrimeA-Gene; Promega, Madison, WI, USA). After $30 \mathrm{~min}$ of pre-hybridization $\left(68^{\circ} \mathrm{C}\right.$, in QuickHyb buffer; Stratagene, La Jolla, CA, USA) the blots were incubated with denatured, labeled probe for $1 \mathrm{~h}$, at $68^{\circ} \mathrm{C}$. High stringency post-hybridization washes to remove nonhybridized probe were done using $0 \cdot 1 \times$ SSC, $0 \cdot 1 \%$ SDS. Blots were exposed to X-ray film at $-80{ }^{\circ} \mathrm{C}$ for $24-72 \mathrm{~h}$. Following exposure, blots were stripped with $0 \cdot 1 \times$ SSC, $0.1 \%$ SDS at $95^{\circ} \mathrm{C}$ (two washes of $15 \mathrm{~min}$ each), and re-probed. Changes in gene expression were quantified using scanning densitometry. RNA loading on the gel was made equal by adjusting for previous assessment of ethidium bromide staining.

To determine low level expression of IGF-I mRNA in primary mammary epithelial cells we used the more sensitive procedure of RNase protection assay (RPA). The RPA was carried out using $\left[{ }^{32} \mathrm{P}\right]$-labeled riboprobes specific for the bovine IGF-I mRNA and glyceraldehyde 3-phosphate dehydrogenase (GAPDH) mRNA. The probes were synthesized using standard in vitro transcriptions. The IGF-I and GAPDH cDNA plasmids used as templates in the in vitro transcriptions were gifts from Matthew C Lucy (University of Missouri, Columbia, MO, USA) and prepared as described previously (Kobayashi et al. 1999). The RPA was performed on $30 \mu \mathrm{g}$ total RNA using the RPA II kit (Ambion) according to the manufacturer's instructions with modifications described previously (Jiang et al. 1999). The protected RNA fragments were resolved on a $6 \%$ acrylamide gel containing $7 \mathrm{M}$ urea. The gel was dried and scanned for signals on a Molecular Imager (BioRad Laboratories, Inc., Hercules, CA, USA).

\section{Radioimmunoassays (RIA) and IGF-I receptor binding assay}

Plasma concentrations of IGF-I and GH were determined by RIA as described previously (McFadden et al. 1990, Purup et al. 1993, Weber et al. 1999). For the IGF-I assay, recombinant human IGF-I purchased from GrowPep (Adelaide, Australia) was used for standards and iodination. Mouse anti-human IGF-I antibody (first antibody) was a gift from Dr Bernard Laarveld (University of Saskatchewan, Saskatchewan, Canada). Goat anti-mouse antiserum (second antibody) was purchased from Sigma Chemical Company (St Louis, MO, USA). IGF-I was radioiodinated as described previously for $\alpha$-lactalbumin (Akers et al. 1986) and the resulting specific activity averaged $38 \mu \mathrm{Ci} / \mu \mathrm{g}$. For assay, standards or unknown samples were suspended in RIA buffer $(30 \mathrm{mM}$ sodium phosphate, $10 \mathrm{mM}$ EDTA, $0.02 \%$ protamine sulfate, $0.05 \%$ Tween-20, $\mathrm{pH} 8 \cdot 0$ ) to a final volume of $500 \mu \mathrm{l}$. Subsequently, $100 \mu \mathrm{l}$ radiolabeled IGF-I $(\sim 30000$ d.p.m.) and $100 \mu \mathrm{l}$ of first antibody $(1: 70000)$ were added to each tube. After $24 \mathrm{~h}$ incubation at $4{ }^{\circ} \mathrm{C}, 100 \mu \mathrm{l}$ of second antibody $(1: 20)$ was added. Tubes were incubated for a further $72 \mathrm{~h}$ at $4{ }^{\circ} \mathrm{C}$. Phosphate-buffered saline $(1.5 \mathrm{ml})$ was added to each tube followed by centrifugation at $1500 \mathrm{~g}$ for $30 \mathrm{~min}$. The tubes were decanted and bound radioactivity was measured by gamma counting. Inter- and intra-assay variation averaged less than $10 \%$. For the GH assay, recombinant bovine GH (lot 6958C-42A; American Cyanamid Company, Princeton, NJ, USA) was iodinated as previously for $\alpha$-lactalbumin (Akers et al. 1986). The iodinated hormone was subjected to gel filtration chromatography using Biogel P60 (100-200 mesh) and a glass BioRad Econo-Pac column $1 \times 30 \mathrm{~cm}$ (BioRad Laboratories, Richmond, CA, USA). Fractions $(0.5 \mathrm{ml})$ were collected and radioactivity was quantified. The peak fraction and first descending fraction were pooled and used for assay. The first antibody, rabbit anti-ovine $\mathrm{GH}$ (NIDDK-anti-oGH-2; AFP-C0123080) was a generous gift from the National Hormone and Pituitary Program (Baltimore, MD, USA) and was used as suggested (final dilution 1:100 000). Briefly, all reagents were added to the 
assay tubes at a single sitting in the sequence: buffer, non-radiolabeled standard or unknown, tracer, and antiserum. After $24 \mathrm{~h}$ at room temperature $100 \mu \mathrm{l}$ of diluted second antibody was added to each of the assay tubes. Second antibody was produced by immunization of sheep with purified rabbit gamma globulin (Pentex Rabbit Gamma Globulins, Fraction II, Lot 82A; Miles Laboratories, Elkart, IN, USA) and was used at a dilution of $1: 15$. Within-assay coefficient of variation averaged $8 \cdot 7 \%$ and between-assay variation $11 \cdot 7 \%$. To measure PRL, purified bovine PRL (NIAMDD-bPrl-6) was iodinated as indicated above. However, the iodinated protein was separated from free iodine by passage of the mixture through a simple ion exchange resin column as described in our assay for $\alpha$-lactalbumin (Akers et al. 1986). The primary antibody, rabbit anti-prolactin (DJB7-0330) was a gift from Dr Douglas Bolt (USDA, Beltsville, MD, USA). Characterization of the antiserum and initial assay validation was reported in Echternkamp et al. (1976). The assay was conducted as above for the GH assay. Between- and within-assay coefficients of variation were less than 10\%. To determine IGF-I receptor binding in mammary tissues, extracts of CFP, MFP and PAR were prepared as described (Weber et al. 1999). Briefly, samples were homogenized in physiological saline (4:1 saline: tissue). Mammary homogenates were shaken for $90 \mathrm{~min}$ at $4{ }^{\circ} \mathrm{C}$, and then centrifuged at $10000 \mathrm{~g}$ to remove cellular debris. Subsequently, the supernatant from each sample was ultra-centrifuged at $100000 \mathrm{~g}$. The supernatant was retained for analysis of IGFBP. The pellets were resuspended in $1 \mathrm{ml}$ receptor buffer and stored for analysis of IGF-I receptor binding. To determine IGF-I receptor binding, $100 \mu \mathrm{g}$ total protein (determined by BCA assay, data not shown) was incubated with ${ }^{125}$ I-IGF-I or ${ }^{125} \mathrm{I}$ IGF-I plus excess IGF-I in a shaker overnight at $4{ }^{\circ} \mathrm{C}$, as previously described (McFadden et al. 1990, Purup et al. 1995). Specific binding was determined by subtracting binding in the presence of excess IGF-I from binding in the presence of ${ }^{125}$ I-IGF-I alone.

\section{Western ligand blots}

Western ligand blots of mammary extracts and serum samples to determine mammary IGFBP abundance was performed as previously described (Hossenlopp et al. 1986). Total protein $(200 \mu \mathrm{g})$ was loaded in each lane. Briefly, samples were dissolved into non-reducing SDSPAGE buffer and electrophoresed through a $12 \%$ SDSPAGE gel at $65 \mathrm{~V}$ for $18 \mathrm{~h}$. After electrophoresis, proteins were transferred to nitrocellulose at $55 \mathrm{~V}$ for $5 \mathrm{~h}$. Blots were incubated in ${ }^{125} \mathrm{I}$-IGF-I $\left(1 \times 10^{6}\right.$ c.p.m. $\left./ \mathrm{ml}\right)$ overnight and washed in Tris-buffered saline to remove unbound ligand. The effects of ovariectomy on serum IGFBP were similarly determined, using $4 \mu \mathrm{l}$ serum from samples taken 1 week before ovariectomy and 1 week before the animals were killed. Blots were exposed to
Kodak X-ray film for 2 weeks at $-80{ }^{\circ} \mathrm{C}$. Scanning densitometry was used to quantify changes in IGFBP levels and purified IGFBP-3 was included as a positive control on each gel.

\section{Statistics}

Statistics were performed using the SAS statistical package version 8.0 (SAS Inc., Cary, NC, USA, 1999). Data for uterus and mammary weights were analyzed using a $t$-test to compare the means from ovariectomized and control heifers. Data for mRNA expression, mammary IGFBP abundance and IGF-I receptor binding were analyzed using the general linear model (GLM) procedure. The model tested for main effects of treatment (ovariectomized or control), tissue (PAR, MFP or CFP) and the treatment $\times$ tissue interaction, with tissue included as a repeated measure. When the treatment $\times$ tissue interaction was significant, $t$-tests were used to make comparisons between individual means. Data for serum IGFBP were also analyzed using the GLM procedure. The model tested for main effects of treatment (ovariectomized or control), time (before and after surgery) and the treatment $\times$ time interaction. Serum hormone data were analyzed using a mixed model (MIXED procedure). The model tested for main effects of treatment (ovariectomized or control), time (weekly time points for the duration of the experiment) and the treatment $\times$ time interaction. Time was included as a repeated measure. Differences of $P<0.05$ were considered significant. Data are presented as least squares (LS) means \pm S.E.M.

\section{Results}

\section{Mammary and uterus development}

Both total mammary $(304 \pm 25 \mathrm{~g}, n=6$, vs $130 \pm 21 \mathrm{~g}$, $n=8 ; P<0 \cdot 001)$ and uterus $(30 \cdot 4 \pm 4.5 \mathrm{~g}, n=6$, vs $14.5 \pm$ $3.8 \mathrm{~g}, n=8 ; P<0 \cdot 05)$ weights were significantly reduced by ovariectomy. Reduced mammary weight in ovariectomized animals corresponded with dramatically reduced development of parenchymal tissue.

\section{Systemic concentrations of GH, IGF-I and PRL}

Serum concentrations of IGF-I, GH and PRL are shown in Fig. 1A. No significant effect of ovariectomy was observed for IGF-I, GH or PRL. Furthermore, there was no significant interaction between treatment (ovariectomized vs control) and time for any of the serum hormones. The only change in hormone concentration was that PRL concentration was significantly higher in both ovariectomized and control animals during the last 6 weeks of the experiment, which is likely related to seasonal changes. 

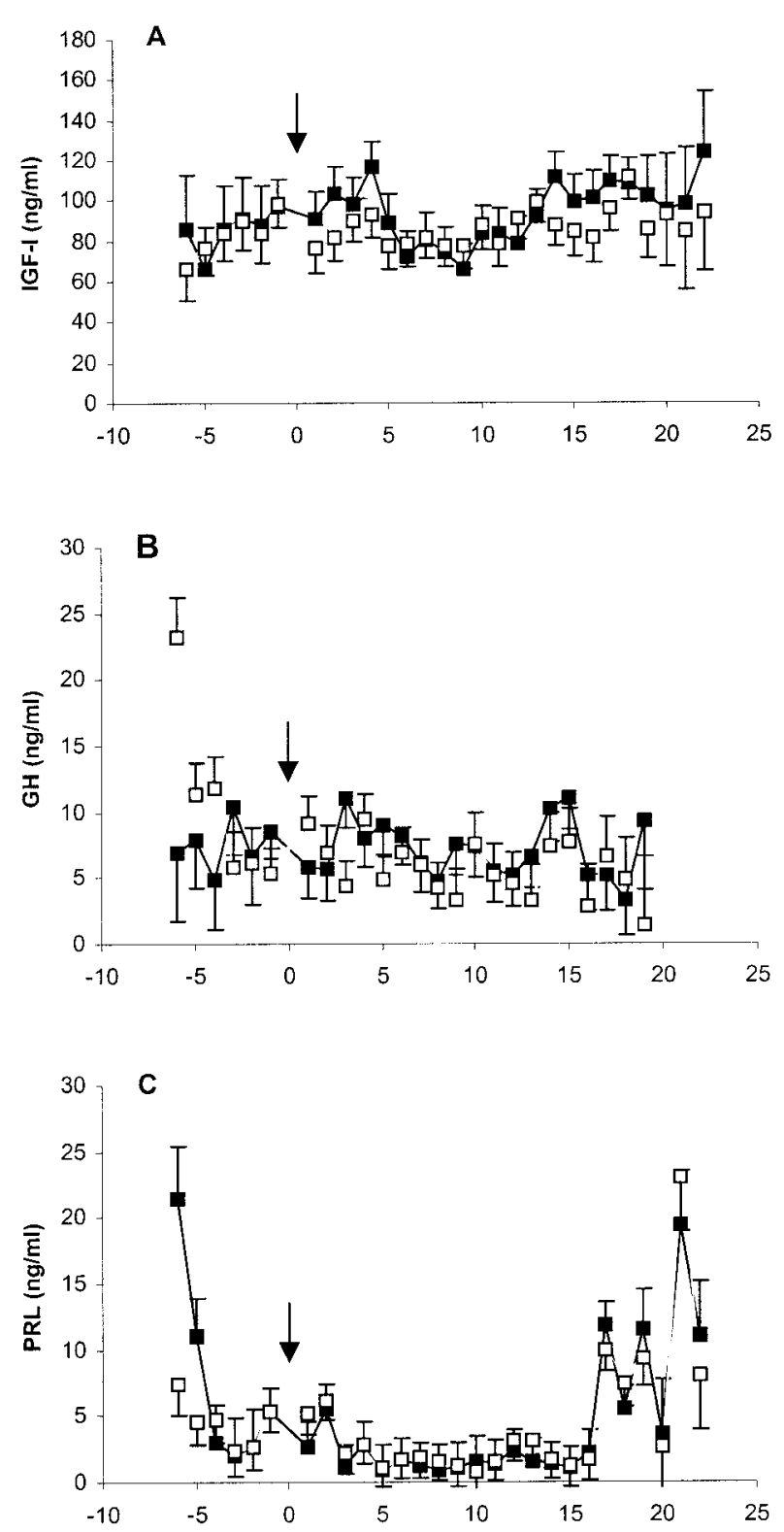

Figure 1 Serum hormone concentrations in control (solid squares; $n=6)$ and ovariectomized (open squares; $n=8$ ) heifers. Time in weeks is related to time of surgery: ovariectomies were performed at time zero (indicated by arrows) as described in Materials and Methods. (A) IGF-I, (B) GH and (C) PRL. Data presented are LS means \pm S.E.M..

Expression of mammary IGF-I $m R N A$ is exclusive to mammary stroma

Previous studies of IGF-I expression in mammary tissue from rodents (Kleinberg 1997) and humans (Yee et al. 1991, Cullen et al. 1992) have shown that IGF-I expression is limited to mammary stromal cells. To test whether this was true in prepubertal heifers, we prepared
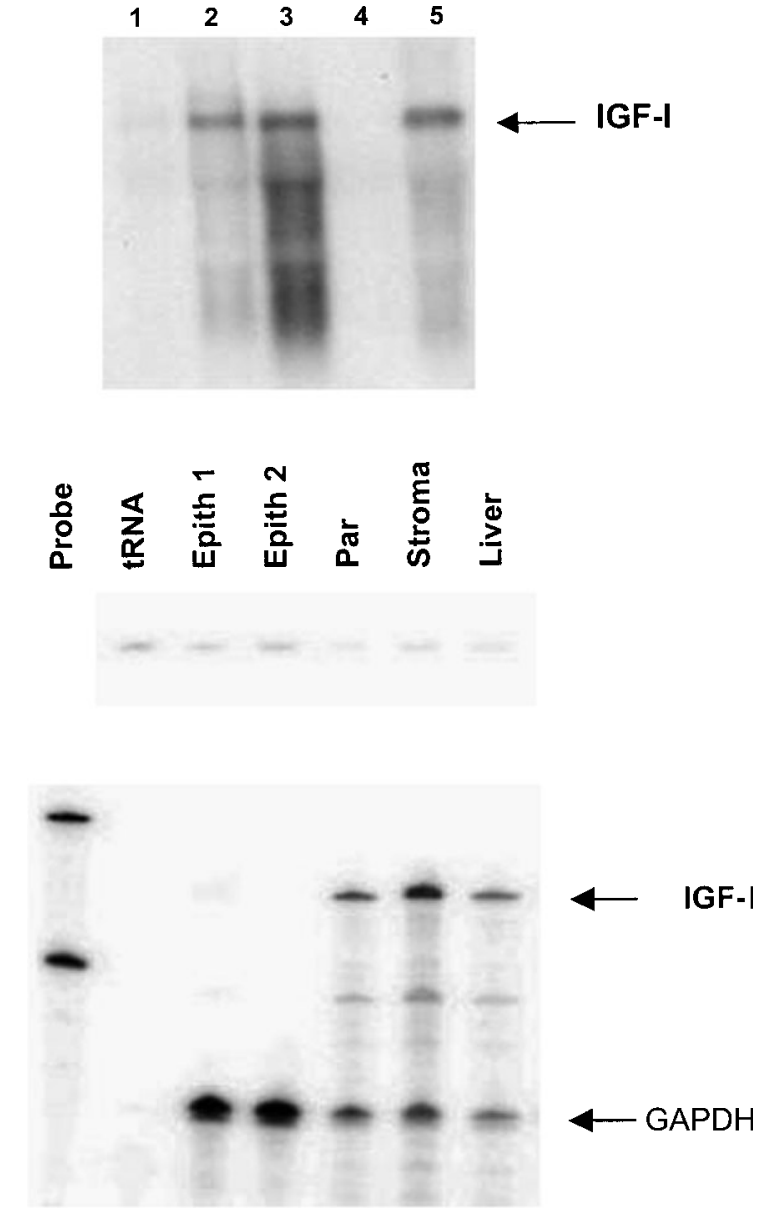

Figure 2 Expression of IGF-I mRNA in bovine mammary tissue is exclusive to stromal cells. The upper panel shows a Northern blot for expression of IGF-I mRNA. Lane 1, purified bovine mammary epithelial cells from a prepubertal heifer; lane 2, bovine prepubertal mammary parenchyma; lane 3 , bovine prepubertal mammary stroma; lane 4, bovine lactating parenchyma; lane 5, bovine liver ( $15 \mu \mathrm{g}$ RNA per lane). The lower panel shows an RNase protection assay for IGF-I expression. GAPDH was used as an internal loading control. Epith 1 and 2 are RNA from epithelial cells isolated from two Holstein heifers. Par is RNA from parenchymal tissue and Stroma is RNA from stromal tissue from heifer mammary gland. The final lane is bovine liver RNA. These are representative results from two separate experiments.

primary mammary epithelial cells from two prepubertal heifers (Weber et al. 1999). Figure 2 shows IGF-I expression in RNA isolated from purified bovine mammary epithelial cells, bovine prepubertal mammary stroma, bovine prepubertal mammary parenchyma, and bovine liver. As expected, an IGF-I transcript was present in bovine liver. Expression of IGF-I was absent from both preparations of primary mammary epithelial cells, but present in both the prepubertal stroma and parenchyma. This observation confirms that IGF-I mRNA expression 


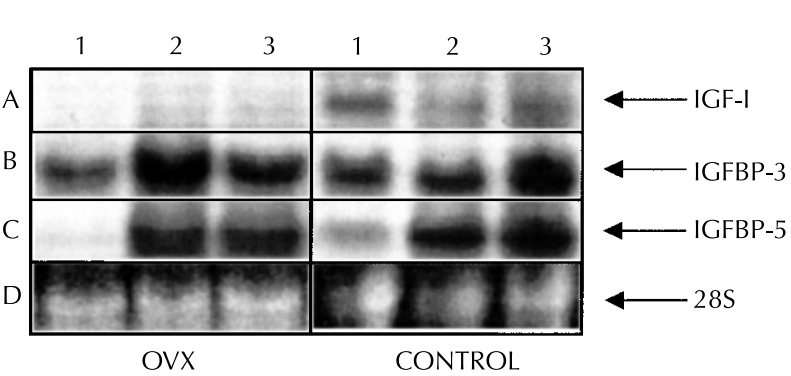

Figure 3 Northern analysis of IGF-I, IGFBP-3 and IGFBP-5 expression in mammary tissue from ovariectomized (OVX) and control heifers. Lane 1, PAR; lane 2, MFP; lane 3, CFP. Samples shown are for one representative animal from each treatment group. Quantification and statistical analysis are shown in Fig. 4.

within mammary parenchymal tissue is derived from interspersed stromal cells such as fibroblasts.

Effect of ovariectomy and epithelial-stromal interactions on $m R N A$ expression of IGF-I, IGFBP-3 and IGFBP-5

Northern analysis of mammary IGF-I mRNA expression revealed one major transcript of approximately $7.5 \mathrm{~kb}$, which was present in both mammary parenchyma and mammary stroma (Figs 3A and 4A). Overall, expression of IGF-I mRNA was lower in ovariectomized animals than in controls (Fig. 4A; significant main effect for treatment: $P<0 \cdot 05)$. In contrast to our hypothesis that IGF-I mRNA expression would be lower in CFP than MFP, IGF-I mRNA levels did not differ between any of the mammary tissue types $(P>0 \cdot 05)$. IGFBP-3 (Figs 3B and 4B) mRNA expression was present as one transcript of approximately $2.5 \mathrm{~kb}$ and did not differ between intact and ovariectomized animals, or between tissue types. IGFBP-5 mRNA expression was not influenced by ovariectomy, but was significantly higher in mammary stroma than mammary parenchyma (Figs $3 \mathrm{C}$ and $4 \mathrm{C} ; P<0 \cdot 001$ ). This finding is similar to a previous study in which IGFBP-5 mRNA was localized to the stromal portion of the rat mammary gland (Manni et al. 1994).

\section{Ovariectomy reduces ${ }^{125}$ I-IGF-I binding to mammary parenchyma}

To test whether ovariectomy reduced the ability of mammary tissue to bind IGF-I, we assayed binding of ${ }^{125}$ I-IGF-I to mammary microsomes. Specific binding of ${ }^{125}$ I-IGF-I to mammary parenchymal microsomes was significantly reduced from a mean of $868 \pm 82$ c.p.m./ $100 \mu \mathrm{g}$ protein in intact animals to $377 \pm 142$ c.p.m./ $100 \mu \mathrm{g}$ protein in ovariectomized animals (Fig. 5; $P<0 \cdot 01) .{ }^{125}$ I-IGF-I binding to microsomes from stromal tissue ranged from 341 to $486 \pm 82$ c.p.m. $/ 100 \mu \mathrm{g}$ protein and did not differ between ovariectomized and control animals, or between MFP and CFP.
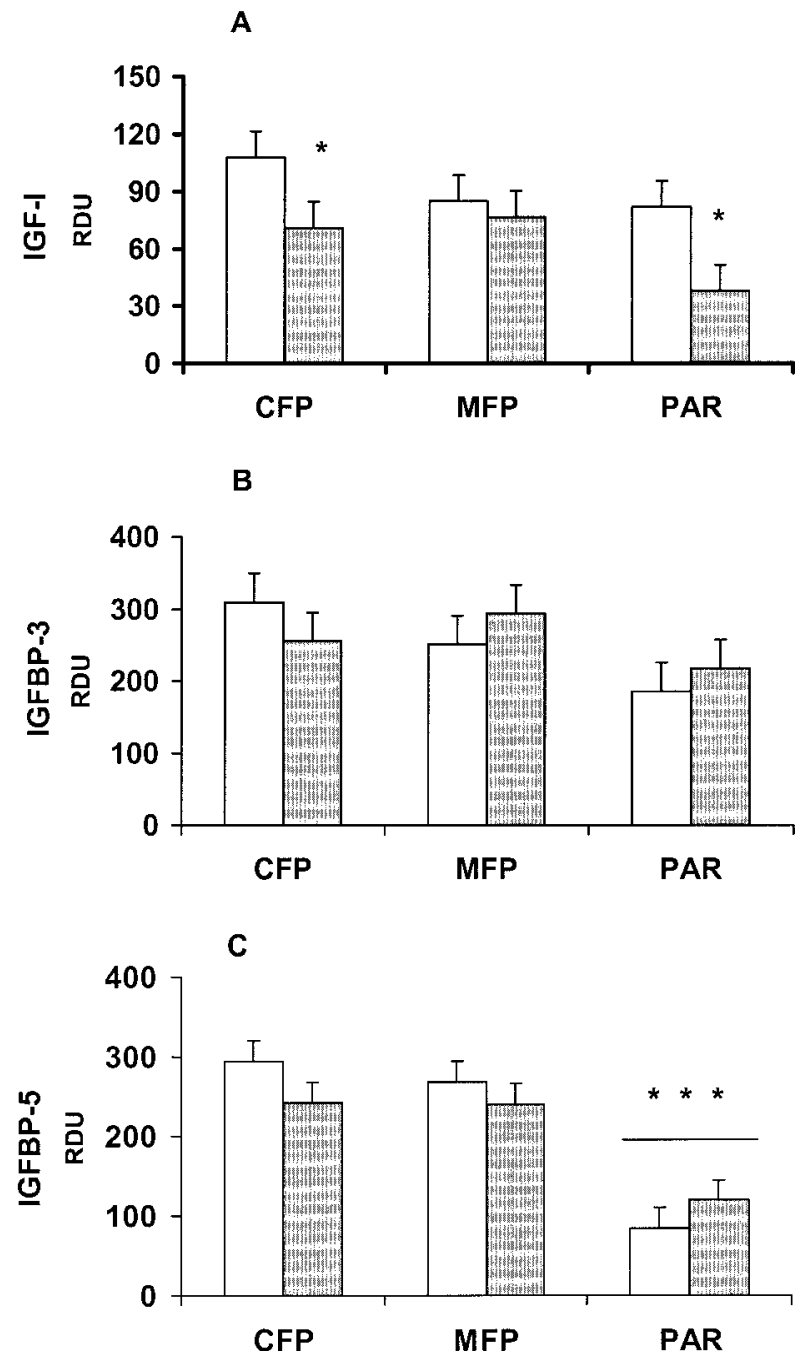

Figure 4 Quantification of mRNA expression of (A) IGF-I, (B) IGFBP-3 and (C) IGFBP-5 in mammary tissue from control (open bars) and ovariectomized (shaded bars) heifers. Data are expressed as relative densitometric units (RDU). Total RNA was equal between lanes as determined by ethidium bromide staining. LS means and S.E. are presented, and significant main effects are described within the text. ${ }^{*} P<0 \cdot 05$ compared with control of same tissue type; ${ }^{* *} P<0 \cdot 001$. Bar and asterisks in $(\mathrm{C})$ indicate overall effect of tissue with PAR lower than CFP or MFP.

\section{Serum and mammary tissue IGFBP}

IGFBP were present in serum and mammary tissue as four major molecular weight bands, ranging between approximately 24 and $46 \mathrm{kDa}$ (Fig. 6). The largest of the IGFBP (43-46 kDa) was likely IGFBP-3 as previously described (Weber et al. 1999, Berry et al. 2001). IGFBP-2 was likely present in the $32-35 \mathrm{kDa}$ band and the lower molecular weight proteins may consist of IGFBP-1 or IGFBP-4. More accurate identification of bovine IGFBP will require specific antibodies to each binding protein. None of the 


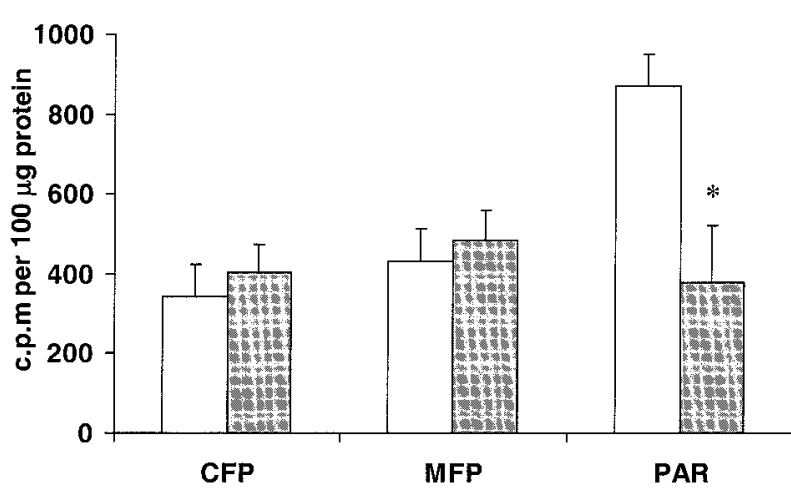

Figure 5 Binding of ${ }^{125}$ I-IGF-I to mammary microsomes from control (open bars) and ovariectomized (shaded bars) heifers. Specific binding was determined by calculating the difference for ${ }^{125}$ I-IGF-I binding in the presence and absence of excess non-radiolabeled IGF-I. Results are presented as specific IGF-I binding (c.p.m.)/100 $\mu$ g microsomal membrane protein. ${ }^{\star} P<0 \cdot 05$ in comparison with control within the same tissue type.

A

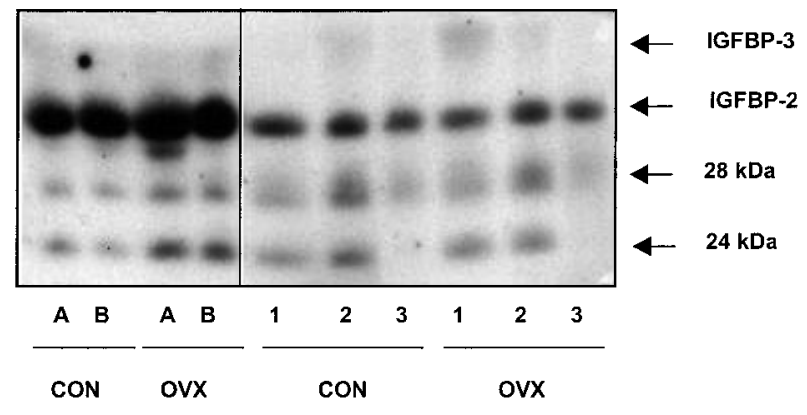

Figure 6 Western ligand blotting of IGFBP in serum and mammary tissue from control (CON) and ovariectomized (OCX) calves. (Panel A) Serum IGFBP in two representative animals (control and ovariectomized) before ovariectomy (A) and 1 week before they were killed (B). (Panel B) Mammary tissue IGFBP in two representative animals (control and ovariectomized): (1) CFP; (2) MFP; (3) PAR.

serum IGFBP was affected by ovariectomy $(P>0 \cdot 05)$. Although we hypothesized that ovariectomy would cause a reduction in mammary IGFBP-3 abundance, this protein was not significantly affected by ovariectomy $(P>0 \cdot 1$; overall treatment means $9205 \pm 1431$ vs $6340 \pm 1752$ RDU for control and ovariectomized animals respectively). Other IGFBPs in mammary tissue were not influenced by ovariectomy except for the $28 \mathrm{kDa}$ protein, which tended to be lower in ovariectomized than in control animals $(P<0 \cdot 06)$.

\section{Discussion}

The importance of systemic hormones such as estrogen, GH and PRL for stimulating and directing mammary development has long been established (Tucker 1981).
However, the complexity of interactions between such hormones and locally produced growth factors is only just beginning to be realized. IGF-I has received considerable attention in recent years for its potential role in mediating the effects of $\mathrm{GH}$ and estrogen on mammary development. As well as reaching the mammary gland via systemic circulation, IGF-I is produced locally within the gland. However, the relative importance of local vs systemic IGF-I in mediating mammary growth is not known. Recently, a study of a conditional knockout mouse model suggested that local IGF-I may be more important than circulating IGF-I in mediating many aspects of growth and development (Liu et al. 2000). These mice lacked liver IGF-I, and had dramatically reduced serum concentrations of IGF-I, but peripheral IGF-I expression was not affected. Interestingly, the knockout mice grew at a rate similar to wild-type controls. Recent studies of IGF-I mRNA and protein expression in bovine mammary tissue also point to a role for locally derived IGF-I in directing mammary development. IGF-I mRNA was highest in mammary tissue from virgin and pregnant cows, and significantly decreased at the onset of lactation (Plath-Gabler et al. 2001). Several lines of evidence from our laboratory also lend support to the hypothesis that local IGF-I is of greater importance in mediating bovine mammary growth. First, mammary extracts are much more potent stimulators of mammary epithelial proliferation than is serum from the same animals (Weber et al. 1999). Much of this mitogenic activity can be attributed to IGF-I because addition of anti-IGF-I antibodies or IGFBP-3 abolishes proliferation. Secondly, administration of estrogen to heifers stimulates mammary epithelial cell proliferation (Berry et al. 2001). In parallel with the increase in cell proliferation, mammary IGF-I protein was increased by estrogen, but systemic concentrations of IGF-I were unchanged. Whether this effect was the result of increased mammary production of IGF-I or increased accumulation of IGF-I within mammary epithelium is unknown. Here, we show that reduced mammary development in ovariectomized animals coincides with reduced mammary IGF-I mRNA expression. In contrast, serum concentrations of IGF-I were unchanged, suggesting that local expression of IGF-I mRNA may play a critical role in mediating mammary development in prepubertal heifers.

Although expression of IGF-I mRNA is observed within the parenchymal and stromal portions of the bovine mammary gland, previous studies of human mammary tissue (Yee et al. 1991, Cullen et al. 1992) have suggested that mammary stromal cells exclusively produce IGF-I. We show here that this is also true within the bovine mammary gland. IGF-I mRNA was not expressed by purified primary bovine mammary epithelial cells, but was expressed in both prepubertal stroma and parenchyma. Thus, the IGF-I mRNA observed within mammary parenchyma must be derived from surrounding stromal cells, as previously hypothesized (Akers et al. 2000). This 
observation is supported by the results of Plath-Gabler et al. (2001), who, using immunohistochemistry, reported that IGF-I protein was visible primarily in adipocytes and fibroblasts but rarely in mammary epithelial cells.

Although systemic estrogen concentrations in the heifers in this study were too low to assay accurately, uterus weight in ovariectomized animals was reduced. This observation is indicative of reduced circulating estrogen (Hipkin 1969). In a previous study, estrogen was significantly reduced in 6-month-old ovariectomized heifers (Purup et al. 1993). The reduction was approximately $0 \cdot 1 \mathrm{pg} / \mathrm{ml}$ (representing about a 50\% decrease), thus raising the question of whether such a small reduction could be responsible for such large changes in mammary development. Possibly, the role of the ovary in prepubertal heifers is mediated through something other than circulating estrogen.

Previous studies have suggested a role for interactions between estrogen and the IGF-I axis in mediating mammary growth; however, the mechanisms by which estrogen may enhance IGF-I action (or vice versa) are unclear. Possibly, estrogen and IGF-I act in a synergistic manner to stimulate mammary epithelial proliferation. Several studies have previously shown that estrogen can enhance transcription of the IGF-I gene in a variety of tissues and species (Umayahara et al. 1994). This supports our observations that IGF-I mRNA is lower in mammary tissue from ovariectomized animals. However, in the bovine mammary gland, it is unlikely that estrogen directly stimulates IGF-I transcription through the estrogen receptor $\alpha(E R \alpha)$, because IGF-I expression is exclusive to stromal cells and the ER $\alpha$ is found only in epithelial cells (Capuco et al. 2002, Berry et al. 2003). However, regulation of IGF-I mRNA expression by estrogen may be controlled through interactions between parenchymal and stromal mammary tissues. For instance, activation of ER $\alpha$ may stimulate expression of a novel paracrine factor which, in turn, may regulate expression of IGF-I expression in adjacent stromal cells. Estrogen may also stimulate IGF-I mRNA expression through ER $\beta$; however, the role of ER $\beta$ in stimulating heifer mammary development has not yet been investigated. Expression and activation of the IGF-I receptor within mammary epithelium may be regulated in part by estrogen, resulting in increased sensitivity of mammary epithelial cells to IGF-I (Kahlert et al. 2000). In support of this hypothesis, we found that mammary parenchymal microsomes from ovariectomized animals were significantly less able to bind ${ }^{125}$ I-IGF-I than those from intact controls. This may lead to reduced IGF-I receptor activation within mammary parenchyma from ovariectomized animals, resulting in reduced epithelial proliferation and mammary growth. Alternatively, estrogen may interact with the downstream components of the IGF-I signaling pathway to alter IGF-I signaling and IGF-I mediated-proliferation. In the rat uterus, estrogen stimulated tyrosine phosphorylation of the IGF-I receptor as well as the IRS-I protein, resulting in increased activation of the IGF-I pathway (Richards et al. 1996). Other growth factor pathways (epidermal growth factor, platelet-derived growth factor) were not affected, demonstrating that the effects of estrogen were specific to the IGF-I pathway. Similarly, estrogen was shown to stimulate phosphorylation of the IRS-I in human mammary epithelial cells (Lee et al. 1999), an effect that was abolished by the presence of anti-estrogens.

As well as the effects of ovariectomy on local expression of IGF-I and IGFBP, we also sought to determine the effects of epithelial-stromal interactions on the expression of the same molecules. Previous ovine work showed that expression of IGF-I mRNA within the mammary gland was influenced by the developing epithelium, suggesting a role for epithelial-stromal interactions in modulating expression of growth factors by the mammary fat pad (Hovey et al. 1998a). However, in this experiment, we have found no evidence for altered IGF-I or IGFBP mRNA expression in the CFP compared with the MFP, suggesting that epithelial-stromal interactions are not important for regulating the expression of local IGF-I axis components in the developing heifer mammary gland. Alternatively, interactions between the stroma and epithelium do regulate IGF-I or IGFBP expression, but only in the region near the epithelium. For example, it is possible that stromal cells immediately adjacent to epithelial cells express a greater amount of IGF-I mRNA on a per cell basis than stromal cells distal to the epithelium. If this were true, our mammary stromal samples, which were taken from just above the epithelial:stromal interface, may not have reflected changes in IGF-I expression in stromal cells immediately adjacent to epithelial cells.

In conclusion, ovariectomy inhibits mammary development in prepubertal heifers and is associated with decreased IGF-I mRNA expression within the mammary gland, as well as decreased binding of IGF-I to mammary parenchymal microsomes. In contrast, no changes were observed in systemic concentrations of IGF-I, GH, PRL or abundance of IGFBP, suggesting that the negative effects of ovariectomy were mediated primarily through changes in the local IGF-I axis. These results suggest a role for interactions between the ovary and the local IGF-I axis in regulating mammary development in heifers. Continuing studies will attempt to elucidate mechanisms of such interactions in promoting mammary epithelial proliferation, IGF-I signaling and growth factor expression within the prepubertal heifer mammary gland.

\section{Acknowledgements}

Technical assistance from Pat Boyle as well as statistical advice from Dr Ron Pearson were gratefully received. We are also grateful for assistance from Curtis Caldwell for management of the calves and from V Soderberg, 
C Fallgren and T Schutrumpf in obtaining blood samples throughout the experiment. Financial assistance was provided by the NRI-USDA grant \#98-9803664. S D K B was the recipient of the C Alma Baker and Frank Sydenham scholarships for graduate study in agriculture.

\section{References}

Akers RM 1990 Lactation physiology: a ruminant animal perspective. Protoplasma 159 96-111.

Akers RM, McFadden TB, Beal WE, Guidry AJ \& Farrell HM 1986 Radioimmunoassay for measurement of bovine alpha-lactalbumin in serum, milk and culture media. Journal of Dairy Research $\mathbf{5 3}$ 419-429.

Akers RM, McFadden TB, Purup S, Vestergaard M, Sejrsen K \& Capuco AV 2000 Local IGF-I axis in peripubertal ruminant mammary development. Journal of Mammary Gland Biology and Neoplasia 5 43-51.

Berry SD, McFadden TB, Pearson RE \& Akers RM 2001 A local increase in the mammary IGF-1:IGFBP-3 ratio mediates the mammogenic effects of estrogen and growth hormone. Domestic Animal Endocrinology 21 39-53.

Berry, SDK, Jobst PM, Ellis SE, Howard RD, Capuco AV \& Akers RM 2003 Mammary epithelial proliferation and estrogen receptor $\alpha$ expression in prepubertal heifers: effects of ovariectomy and growth hormone. Journal of Dairy Science (In Press).

Capuco AV, Ellis S, Wood DL, Akers RM \& Garrett W 2002 Postnatal mammary ductal growth: three dimensional imaging of cell proliferation, effects of estrogen, and expression of steroid receptors in prepubertal calves. Tissue and Cell 34 143-154.

Cullen KJ, Allison A, Martire I, Ellis M \& Singer C 1992 Insulin-like growth factor expression in breast cancer epithelium and stroma. Breast Cancer Research and Treatment 22 21-29.

Echternkamp SE, Bolt DJ \& Hawk HW 1976 Ovarian and pituitary hormones in blood of progesterone-treated ewes. Journal of Animal Science 42 893-900.

Hipkin LJ 1969 Nonspecific inhibition of gonadotropin in the uterine weight assay. Endocrinology 84 482-487.

Hossenlopp P, Seurin D, Segovia-Quinson B, Hardouin S \& Binoux M 1986 Analysis of serum insulin-like growth factor binding proteins using western blotting: use of the method for titration of the binding proteins and competitive binding studies. Analytical Biochemistry 154 138-143.

Hovey RC, Davey HW, Mackenzie DD \& McFadden TB 1998a Ontogeny and epithelial-stromal interactions regulate IGF expression in the ovine mammary gland. Molecular and Cellular Endocrinology 136 139-144.

Hovey RC, Mackenzie DDS \& McFadden TB $1998 b$ The proliferation of mouse mammary epithelial cells in response to specific mitogens is modulated by the mammary fat pad in vitro. In Vitro Cellular and Developmental Biology 34 385-392.

Hovey RC, McFadden TB \& Akers RM 1999 Regulation of mammary gland growth and morphogenesis by the mammary fat pad: a species comparison. Journal of Mammary Gland Biology and Neoplasia 4 53-68.

Hovey RC, Auldist DE, Mackenzie DDS \& McFadden TB 2000 Preparation of an epithelium-free mammary fat pad and subsequent mammogenesis in ewes. Journal of Animal Science 78 2177-2185.

Jiang H, Okamura CS \& Lucy MC 1999 Isolation and characterization of a novel promoter for the bovine growth hormone receptor gene. Journal of Biological Chemistry 274 7893-7900.

Kahlert S, Nuedling S, van Eickels M, Vetter H, Meyer R \& Grohe C 2000 Estrogen receptor alpha rapidly activates the IGF-1 receptor pathway. Journal of Biological Chemistry 275 18447-18453.

Kleinberg DL 1997 Early mammary development: growth hormone and IGF-I. Journal of Mammary Gland Biology and Neoplasia 2 49-57.
Kobayashi Y, Boyd CK, Bracken CJ, Lamberson WR, Keisler DH \& Lucy MC 1999 Reduced growth hormone receptor (GHR) messenger ribonucleic acid in liver of periparturient cattle is caused by a specific down-regulation of GHR 1A that is associated with decreased insulin-like growth factor I. Endocrinology 140 3947-3954.

Lee AV, Jackson JG, Gooch JL, Hilsenbeck SG, Coronado-Heinsohn E, Osborne CK \& Yee D 1999 Enhancement of insulin-like growth factor signaling in human breast cancer: estrogen regulation of insulin receptor substrate- 1 expression in vitro and in vivo. Molecular Endocrinology 13 787-796.

Liu JL, Yakar S \& LeRoith D 2000 Conditional knockout of mouse insulin-like growth factor-1 gene using the Cre/loxP system. PNAS 223 344-351.

McFadden TB, Daniel TE \& Akers RM 1990 Effects of plane of nutrition, growth hormone and unsaturated fat on growth hormone, insulin and prolactin receptors in prepubertal lambs. Journal of Animal Science 68 3180-3189.

Manni A, Badger B, Wei L, Zaenglein A, Grove R, Khin S, Heitjan D, Shimasaki S \& Ling N 1994 Hormonal regulation of insulin-like growth factor II and insulin-like growth factor binding protein expression by breast cancer cells in vivo: evidence for stromal epithelial interactions. Cancer Research 54 2934-2942.

Ohlsen SM, Dean DM \& Wong EA 1993 Characterization of multiple transcription initiation sites of the ovine insulin-like growth factor-1 gene and expression profiles of three alternatively spliced transcripts. DNA and Cell Biology 12 243-251.

Plath-Gabler A, Gabler C, Sinowatz F, Berisha B \& Schams D 2001 The expression of the IGF family and GH receptor in the bovine mammary gland. Journal of Endocrinology 168 39-48.

Purup S, Sejrsen K, Foldager J \& Akers RM 1993 Effect of exogenous bovine growth hormone and ovariectomy on prepubertal mammary growth, serum hormones and acute in vitro proliferative response of mammary explants from Holstein heifers. Journal of Endocrinology 139 19-26.

Purup S, Sejrsen K \& Akers RM 1995 Effect of bovine GH and ovariectomy on mammary tissue sensitivity to IGF-I in prepubertal heifers. Journal of Endocrinology 144 153-158.

Richards RG, DiAugustine RP, Petrusz P, Clark GC \& Sebastian J 1996 Estradiol stimulates tyrosine phosphorylation of the insulin-like growth factor- 1 and insulin receptor substrate- 1 in the uterus. PNAS 93 12002-12007.

Romagnolo D, Akers RM, Byatt JC, Wong EA \& Turner JD 1994 Regulation of expression of IGF-I induced IGFBP-3 and IGF-I receptor by constitutive versus regulated expression of recombinant IGF-I in transfected mammary epithelial cells. Endocrine Journal 2 375-384.

Ruan W, Catanese V, Wieczorek R, Feldman M \& Kleinberg DL 1995 Estradiol enhances the stimulatory effect of insulin-like growth factor-I (IGF-I) on mammary development and growth hormoneinduced IGF-I messenger ribonucleic acid. Endocrinology 136 1296-1302.

Sejrsen K, Foldager J, Sorensen MT, Akers RM \& Bauman DE 1986 Effect of exogenous bovine somatotropin on pubertal mammary development in heifers. Journal of Dairy Science 69 1528-1535.

Sejrsen K, Purup S, Vestergaard M \& Foldager J 2000 High body weight gain and reduced bovine mammary growth: physiological basis and implications for milk yield potential. Domestic Animal Endocrinology 19 93-104.

Sinha YN \& Tucker HA 1968 Mammary development and pituitary prolactin level of heifers from birth through puberty and during the estrous cycle. Journal of Dairy Science 52 507-512.

Sinowatz F, Schams D, Kolle S, Plath A, Lincoln D \& Waters MJ 2000 Cellular localisation of GH receptor in the bovine mammary gland during mammogenesis, lactation and involution. Journal of Endocrinology 166 503-510. 
Smith EP, Dickson BA \& Chernausek SD 1990 Insulin-like growth factor binding protein-3 secretion from cultured rat sertoli cells: dual regulation by follicle stimulating hormone and insulin-like growth factor-1. Endocrinology 127 244-251.

Topper YJ \& Freeman CS 1980 Multiple hormone interactions in the developmental biology of the mammary gland. Physiological Reviews 60 1049-1106.

Tucker HA 1981 Physiological control of mammary growth, lactogenesis, and lactation. Journal of Dairy Science $\mathbf{6 4}$ 1403-1421.

Umayahara Y, Kawamori R, Watada H, Imano E, Iwama N, Morishima T, Yamasaki Y, Kajimoto Y \& Kamada T 1994 Estrogen regulation of the insulin-like growth factor I gene transcription involves an AP-1 enhancer. Journal of Biological Chemistry $26916433-16442$.

Weber MS, Purup S, Vestergaard M, Ellis SE, Scndergord-Andersen J, Akers RM \& Sejrsen K 1999 Contribution of insulin-like growth factor (IGF)-I and IGF-binding protein-3 to mitogenic activity in bovine mammary extracts and serum. Journal of Endocrinology 161 365-373.
Weber MS, Purup S, Vestergaard M, Akers RM \& Sejrsen K 2000 Regulation of local synthesis of insulin-like growth factor-I and binding proteins in mammary tissue. Journal of Dairy Science $\mathbf{8 3}$ $30-37$.

White ME, Diao R, Hathaway MR, Mickelson J \& Dayton WR 1996 Molecular cloning and sequence analysis of the porcine insulin-like growth factor binding protein -5 complementary deoxyribonucleic acid. Biochemical and Biophysical Research Communications 218 248-253.

Woodward TL, Beal WE \& Akers RM 1993 Cell interactions in initiation of mammary epithelial proliferation by oestradiol and progesterone in prepubertal heifers. Journal of Endocrinology 136 $149-157$.

Yee D, Rosen N, Favoni RE \& Cullen KJ 1991 The insulin-like growth factors, their receptors, and their binding proteins in human breast cancer. Cancer Treatment and Research 53 93-106.

Received in final form 4 February 2003

Accepted 7 February 2003 